\title{
The Effect of Quality of Education Services on Perceptions of Educational Costs and Student Trust and Their Impact on Student Satisfaction at SMA Negeri Ujungbatu
}

\author{
Septia Syafriani ${ }^{1,2 *}$, Suarman ${ }^{2}$, Henny Indrawati ${ }^{2}$ \\ ${ }^{1}$ SMA Negeri 1 Ujungbatu, Ujungbatu, Rokan Hulu, 28553, Indonesia \\ ${ }^{2}$ Faculty of Teacher Training and Education, Pekanbaru, 28293, Indonesia
}

\section{ARTICLE INFO}

\section{Article history:}

Received: 06 Dec 2020

Revised: 21 June 2021

Accepted: 27 June 2021

Published online: 24 July 2021

\section{Keywords:}

Quality of Education Services Perception of Education Costs Student Trust

Student Satisfaction

\begin{abstract}
A B S T R A C T
This study aims to analyze the effect of the quality of education services on perceptions of education costs and student confidence and their impact on student satisfaction at SMA Negeri Ujungbatu. The population of this research is the students of Class XI SMA Negeri Ujungbatu as many as 475 students. The study was conducted with a sample of 217 students taken by simple random sampling technique. Data was collected using a questionnaire. The data analysis used in this research is descriptive quantitative and path analysis. The results showed that there was an influence between the quality of education services on perceptions of education costs and student confidence and the impact on student satisfaction at SMA Negeri Ujungbatu. The meaning is that the better the quality of educational services provided by the school and the more positive students perceive the cost of education, the more students will believe in the education in the school, it will increase the satisfaction felt by students
\end{abstract}

\section{Introduction}

Education is one of the most effective tools for changing human beings, education has the task of improving the quality of individuals to be more productive. The impact of education in the formation of human quality is two or three times stronger than others, education functions as a social controller, cultural preservation, training center and workforce development and attitude formation. In Indonesia, efforts in education development are also carried out at various levels, from basic education, secondary education to higher education (Indrawati, 2013). 
Education in general still faces problems in relation to the relevance of curriculum, learning and school management which creates a low quality student learning process (rote learning). The learning process does not grow the potential and creativity of students, but presents the theory and knowledge that is memorized with solid theoretical content, coupled with the cost of education which does not seem cheap. This kind of learning process has become a learning culture for students in Indonesia, especially in primary and secondary education, including in high school. Schools have not been able to create a comfortable, interesting and fun learning process for students to learn optimally, so that student learning achievement is low and seems to be getting worse lately (Suryadi, 2010; Indrawati, 2019).

In the business world, customer satisfaction is one of the keys to the success of a business. This is because by satisfying customers, the organization can increase its profit level and get a wider market share. Customer satisfaction is a customer's perception of one type of service experience they experience. Basically there is a close relationship between the determination of service quality and customer satisfaction. If the service received or perceived is as expected, then the service quality is perceived as good and satisfactory and vice versa. Thus, whether or not service quality is good depends on the ability of service providers to consistently meet customer expectations (Murty, 2014).

Likewise in the business world, in the world of education measuring the level of student satisfaction with educational services is important to find out how well the services have been provided by the school. Schools as educational service providers need to learn and have the initiative to improve customer satisfaction because education is a circular process that influences each other and is continuous. Therefore, a marketing strategy for educational services is needed to win the competition between schools and to increase the acceleration of improving the quality and professionalism of school management. The community as school customers (students, parents, and other related parties) needs to be convinced that the school to be chosen is a school that provides services that are relevant to the needs and demands of the times (Murty, 2014).

In Ujungbatu, there are two SMANs, namely SMAN 1 and 2 Ujungbatu. From the initial survey that has been carried out, it is known that the services at SMAN have met educational standards. This is evidenced by, among others, the accreditation of schools that have received an A grade and seen from the number of students who enroll in this high school, the number always increases every year. The predicate of $\mathrm{A}$ accreditation achieved by SMAN 1 and 2 Ujungbatu should be able to show that the educational services provided to students have reached or even exceeded the minimum standards set by the government.

However, in reality, based on observations through direct interviews with students, data obtained that $65 \%$ or most of the students felt they were still not satisfied with the services provided by the school, this was indicated by students being dissatisfied with their decision to attend this school because they were considered not in line with expectations students when they first register. 
Educational services provided by schools, namely school facilities and infrastructure that have not been adequate, have become a classic complaint submitted by students. It also causes students to feel dissatisfied.

According to Tjiptono (2015), there are several factors that influence satisfaction, namely product, price, promotion, location, service, facilities, and atmosphere. Lupiyoadi \& Hamdani (2008), also found that satisfaction is influenced by product quality, service, emotion, price, and cost. Meanwhile, Irawan \& Juwandi (2004), stated that satisfaction is influenced by product quality, price, service quality, emotionality, and convenience.

Several studies have found the quality of educational services to be the most influential factor in student satisfaction. The quality of education services is the most important thing for service providers. Therefore, service providers must understand how to build service quality, identify gaps that may occur, and their effect on student satisfaction and student behavior after using services (Lupiyoadi \& Hamdani, 2008). Education services are all activities carried out by schools that organize teaching and learning processes, provide facilities that support learning, and administration related to learning. Quality learning and teaching processes will be a dream, both for schools and students as the main customers (Mahmud, 2012). The quality of education is very dependent on teachers who play a role and are the biggest contributors in the world of education. Improving the quality of education is a development goal in the field of national education and is an inseparable part of efforts to improve the quality of the whole human being (Desmita et al., 2021; Siagian et al., 2018).

In addition to the quality of educational services, the cost of education also affects student satisfaction. The cost of education is an important component in the educational process because without it, the educational process will not run smoothly (Wijaya, 2009). The cost of education affects the educational process, this is because the cost of education is defined as the amount of money generated and spent for various educational needs (Sutriayu et al., 2020).

Student trust also affects student satisfaction according to Wuryan \& Legowo (2009), that there is a significant and positive influence between trust and student satisfaction. Students' trust in schools is based on knowledge, truth, or news and word of mouth references (Murty, 2014). Student trust is the expectation that students have for the school for the reliability of services and the reliability of the school in fulfilling its promises (Loureiro et al., 2014).

Suhardan \& Suharto (2009), suggest that student satisfaction is the goal of learning services in schools. In this case, students who are satisfied with the learning services provided by the school will certainly show a positive attitude. This definition is not much different from the opinion (Sumaedi et al., 2011), which defines student satisfaction as an emotional evaluation of various outcomes and experiences related to education that they actually get compared to expectations. Based on the description that has been stated, it is important to conduct this research with the aim of analyzing the effect of the quality of 
education services on perceptions of education costs and student confidence and their impact on student satisfaction at SMA Negeri Ujungbatu.

\section{Methodology}

This study is a quantitative descriptive study that aims to analyze the effect of the quality of education services on perceptions of education costs and student confidence and their impact on student satisfaction at SMAN Ujungbatu. The sample in this study were students of class XI SMAN Ujungbatu. The sampling technique used Simple Random Sampling, in order to obtain a sample of 217 students from 475 populations. Data collection techniques was using a questionnaire. The measurement instrument used a Likert scale to measure the quality of educational services, perceptions of the cost of education, student confidence, and student satisfaction.

The validity test was first carried out to test the extent to which the accuracy or accuracy of an instrument as a measuring instrument for research variables was carried out using the Corrected Item-Total Correlation. Reliability test is carried out to determine the extent to which the results of a measurement can be trusted using Cronbach's Alpha. The results of the instrument trial were 41 statements, found that two statements were declared invalid. The research data was tested with the prerequisite analysis test, namely the normality test. The data analysis technique in this research is quantitative descriptive analysis and path analysis.

The results of descriptive statistics will be divided into 3 categories, namely if the mean score is in the value of $1-2.33$ then it is in the low category, if the mean score is in the value of $2.34-3.66$ then it is in the medium category, and if the mean score is at a value of $3.67-5$ then it is in the high category as shown in Table 1.

Table 1. Subject Mean Score Category Norm

\begin{tabular}{cc}
\hline Category & Skor Mean \\
\hline Low & $1-2,33$ \\
Middle & $2,34-3,66$ \\
High & $3,67-5$
\end{tabular}

Source: Sugiyono (2013)

The data analysis technique uses path analysis with substructures presented in Figure 1. 


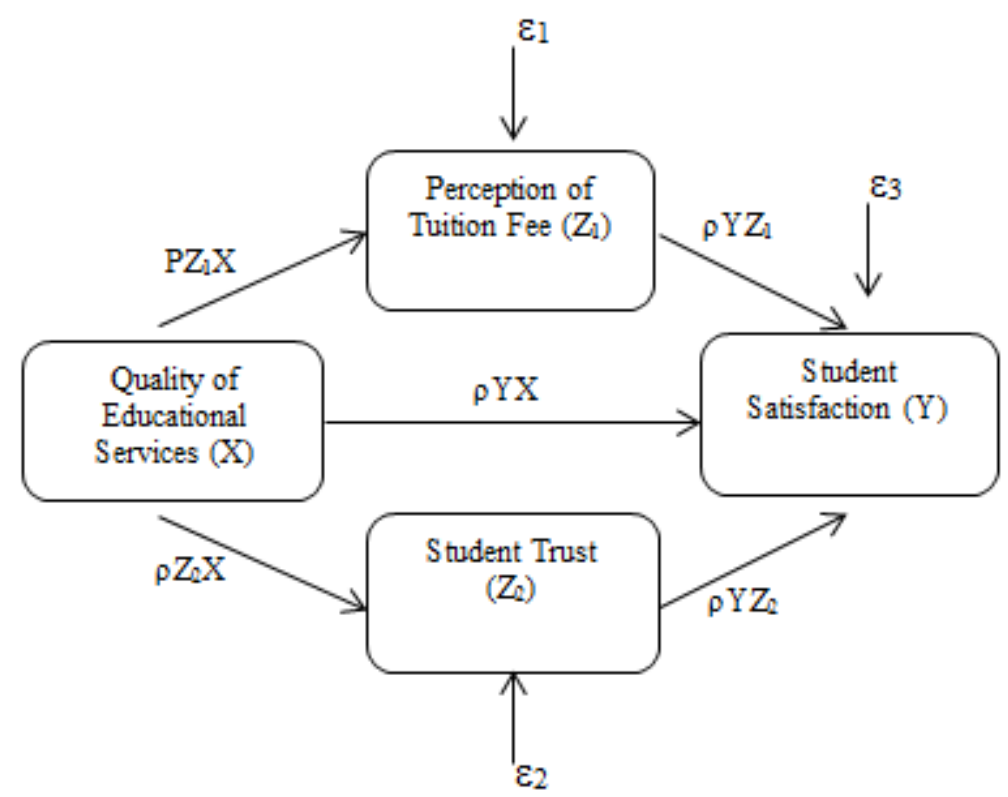

Figure 1. Conceptual Design of Education Service Quality on Perceptions of Educational Costs and Student Trust and Their Impact on Student Satisfaction

According to Figure 1. the following three equations are obtained

With the equation $Z_{1}=\rho Z_{1} X+\varepsilon_{1}$

With the equation $Z_{2}=\rho Z_{2} X+\varepsilon_{2}$

With the equation $Y=\rho Y X+\rho Y Z_{1}+\rho Y Z_{2}+\varepsilon_{3}$

The following is a description of the indicators for each variable as presented in Table 2.

Table 2. Operationalization of Research Variables

\begin{tabular}{|c|c|c|}
\hline Variabel & Indicator & No. Item \\
\hline \multirow{6}{*}{$\begin{array}{l}\text { Student satisfaction (Y) is a } \\
\text { feeling of pleasure shown } \\
\text { by a student towards the } \\
\text { services provided by the } \\
\text { school because his needs } \\
\text { and desires have been } \\
\text { fulfilled. }\end{array}$} & $\begin{array}{l}\text { 1. The level of satisfaction with the } \\
\text { school based on their own decisions }\end{array}$ & 1 \\
\hline & $\begin{array}{l}\text { 2. The level of satisfaction with school } \\
\text { through the desire to re-enroll in the } \\
\text { same school in the future }\end{array}$ & 2 \\
\hline & $\begin{array}{l}\text { 3. The level of confidence choosing } \\
\text { this school is the best choice }\end{array}$ & 3 \\
\hline & $\begin{array}{l}\text { 4. The level of satisfaction with the } \\
\text { decision to enroll in this school }\end{array}$ & 4 \\
\hline & $\begin{array}{l}\text { 5. The level of satisfaction in making } \\
\text { the decision to enroll in this school }\end{array}$ & 5 \\
\hline & $\begin{array}{l}\text { 6. The level of satisfaction of being } \\
\text { part of this school. }\end{array}$ & 6 \\
\hline \multirow{2}{*}{$\begin{array}{l}\text { Quality of education } \\
\text { services }(\mathrm{X}) \text { is a measure of } \\
\text { the level of excellence in }\end{array}$} & 1. Physical evidence & $1,2,3,4,5,6,7,8,9,10$ \\
\hline & 2. Reliability & $11,12,13,14$ \\
\hline
\end{tabular}




\begin{tabular}{|c|c|c|}
\hline \multirow{3}{*}{$\begin{array}{l}\text { managing education } \\
\text { effectively and efficiently. }\end{array}$} & 3. Responsiveness & $15,16,17$ \\
\hline & 4. Guarantee & $18,19,20$ \\
\hline & 5. Attention & $21,22,23$ \\
\hline \multirow{4}{*}{$\begin{array}{l}\text { Perception of the cost of } \\
\text { education (Z1) is a } \\
\text { perspective/response to } \\
\text { resources in the form of } \\
\text { money or goods obtained } \\
\text { from various parties that are } \\
\text { used to support education in } \\
\text { schools with regard to the } \\
\text { implementation } \\
\text { education. }\end{array}$} & $\begin{array}{l}\text { 1. The cost of education is quite } \\
\text { affordable }\end{array}$ & 1 \\
\hline & $\begin{array}{l}\text { 2. The cost of education is competitive } \\
\text { with other similar schools }\end{array}$ & 2 \\
\hline & $\begin{array}{l}\text { 3. The cost of education in accordance } \\
\text { with the services provided }\end{array}$ & 3 \\
\hline & 4. Reasonable cost & 4 \\
\hline \multirow{3}{*}{$\begin{array}{l}\text { Student trust (Z2) is the } \\
\text { student's expectation or } \\
\text { belief in the quality of } \\
\text { education services in } \\
\text { schools. }\end{array}$} & 1. Integrity & $1,2,3$ \\
\hline & 2. Credibility & $4,5,6$ \\
\hline & 3. School reputation & 7,8 \\
\hline
\end{tabular}

\section{Results and Discussion}

\section{Characteristics of Respondents}

Characteristics of respondents based on gender are used to distinguish male and female respondents. The number of respondents by gender can be seen in Table 3 .

Table 3. Profile of Respondents at SMAN Ujungbatu

\begin{tabular}{crccc}
\hline No. & School name & Women & Man & Total \\
\hline 1. & SMAN 1 Ujungbatu & 85 & 56 & 141 \\
2. & SMAN 2 Ujungbatu & 56 & 20 & 76 \\
\hline & Total & 141 & 76 & 217 \\
\hline
\end{tabular}

Table 3 shows that there are more female respondents than male respondents.

\section{Descriptive Analysis Results}

\section{a. Student satisfaction}

Data was obtained based on a questionnaire given to students of SMAN Ujungbatu with 217 students as respondents. There are 6 statement items regarding student satisfaction using a Likert scale with choices from 1 to 5 . The highest score is 30 and the lowest score is 6 . Based on the data from the research, it can be seen that student satisfaction is in Table 4 . 
Table 4. Distribution of Student Satisfaction Frequency

\begin{tabular}{cccc}
\hline Category & Interval & Frekuensi & Persentase \\
\hline Low & $1-2,33$ & 37 & 17,1 \\
Middle & $2,34-3,66$ & 109 & 50,2 \\
High & $3,67-5$ & 71 & 32,7 \\
\hline & & 217 & 100 \\
\hline
\end{tabular}

Table 4 illustrates that the overall results of student satisfaction at SMAN Ujungbatu are in the medium category. This is obtained from the average of 3.0913. However, there are still 37 students $(17.1 \%)$ of student satisfaction in the low category. This is because in the questionnaire statement item number 2 there are 55 students who are not satisfied if there is an option to register at this school again. This means that students still do not have high satisfaction with learning activities and the state of education in the school.

\section{b. Quality of education service}

Data was obtained based on a questionnaire given to students of SMAN Ujungbatu with 217 students as respondents. There are 21 statement items regarding the quality of educational services using a Likert scale with choices from 1 to 5. The highest score is 105 and the lowest score is 21 . Based on the data from the research, it can be seen the quality of education services in Table 5.

Table 5. Frequency Distribution of Education Service Quality

\begin{tabular}{cccc}
\hline Category & Interval & Frequency & Persentase \\
\hline Low & $1-2,33$ & 4 & 1,8 \\
Middle & $2,34-3,66$ & 152 & 70,1 \\
High & $3,67-5$ & 61 & 28,1 \\
\hline & & 217 & 100
\end{tabular}

Table 5 illustrates that the overall results of the quality of education services at SMAN Ujungbatu are in the medium category. This is obtained from the average of 3.3203. However, there are still 4 students $(1.8 \%)$ of student satisfaction in the low category. This is because in the questionnaire statement item number 8 there were 86 students who stated that they were not good with the number, size, and toilet facilities owned by the school. This means that schools still need support facilities so that the quality of education services in schools is getting better by increasing physical (tangible) facilities.

c. Perception of the cost of education

Data was obtained based on a questionnaire given to students of SMAN Ujungbatu with 217 students as respondents. There are 4 statement items regarding the perception of the cost of education using a Likert scale with choices 
from 1 to 5 . The highest score is 20 and the lowest score is 4 . Based on the data from the research, it can be seen the perception of the cost of education in Table 6 .

Table 6. Distribution of the Perceived Frequency of Education Costs

\begin{tabular}{cccc}
\hline Category & Interval & Frequency & Persentase \\
\hline Low & $1-2,33$ & 25 & 11,5 \\
Mid & $2,34-3,66$ & 110 & 50,7 \\
High & $3,67-5$ & 82 & 37,8 \\
\hline & & 217 & 100 \\
\hline
\end{tabular}

Table 6 illustrates that the results of the overall perception of the cost of education at SMAN Ujungbatu are in the medium category. This is obtained from the average of 3.3525. However, there are still 25 students (11.5\%) who perceive the cost of education in the low category. This is because in the questionnaire statement item number 4 there are as many as 51 students who stated that they did not agree if the tuition fees at this school were only collected if there was a need for the students' own interests. This means that there is still funding provided by the school, which is proven that there are still fees charged to students.

\section{d. Student trust}

Data was obtained based on a questionnaire given to students of SMAN Ujungbatu with 217 students as respondents. There are 8 statement items regarding student confidence using a Likert scale with choices from 1 to 5 . The highest score is 40 and the lowest score is 8 . Based on the data from the research, it can be seen that the students' confidence in Table 7 .

Table 7. Distribution of Student Trust Frequency

\begin{tabular}{cccc}
\hline Category & Interval & Frequency & Persentase \\
\hline Low & $1-2,33$ & 7 & 3,3 \\
Mid & $2,34-3,66$ & 119 & 54,8 \\
High & $3,67-5$ & 91 & 41,9 \\
\hline & Total & & 217 \\
\hline
\end{tabular}

Table 7 illustrates that the results of the overall perception of the cost of education at SMAN Ujungbatu are in the medium category. This is obtained from the average of 3.5100. However, there are still 7 students $(3.3 \%)$ of students' confidence in the low category. This is because in the questionnaire statement item 7 there are as many as 45 students who disagree if the school is known to have a high level of discipline. This means that there are still students who have low confidence, this condition is one of the formations of students' distrust of the school. 


\section{Path Analysis}

\section{Sub structure I}

The effect of the quality of education services on the perception of the cost of education is shown in Table 8.

Table 8. The Effect of Education Service Quality (X) on Perceptions of Educational Costs (Z1)

\begin{tabular}{cccc}
\hline Variabel & Koefisien Path & Sig(p) & R Square \\
\hline $\mathrm{X} \rightarrow \mathrm{Z}_{1}$ & 0,585 & 0,000 & 0,343 \\
\hline
\end{tabular}

Table 8 shows that the probability value $(\rho)$ of the quality of education services $(\mathrm{X})$ on the variable perception of the cost of education $(\mathrm{Z} 1)$ is 0.000 because $(0)<$, 0.05 , then at the $5 \%$ error level the path is significant. This means that the quality of educational services affects the perception of the cost of education.

$\varepsilon=\sqrt{1-R^{2}}=\sqrt{1-(0,343)^{2}}=\sqrt{0,882351}=0,882$

If the results of this path analysis are described in sub-structure I, it will be seen in Figure 2.

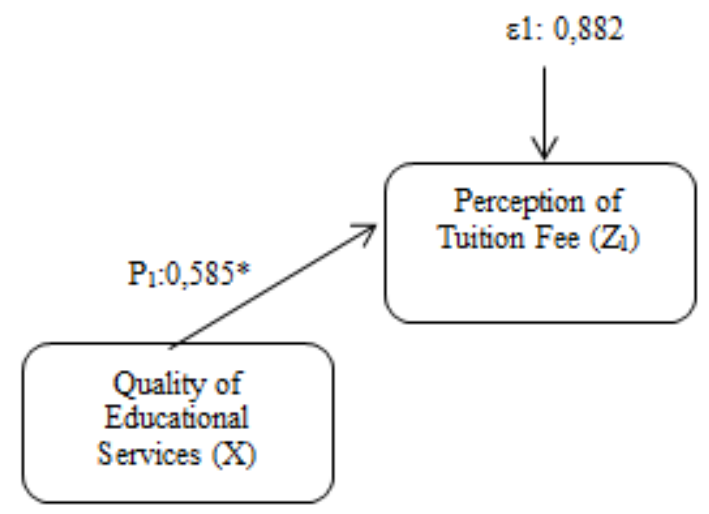

Figure 2. The Effect of Education Service Quality on Perception Cost of education

With the equation $\quad Z_{1}=\rho Z_{1} X+\varepsilon_{1}$

$$
Z_{1}=0,585 X+0,882
$$

This means that the equation shows that the variable quality of education services (X) has a significant direct influence on the perception of the cost of education (Z1) of 0.585 . From this it is known that there is an effect of the quality of education services on the perception of the cost of education with an error of 0.882 . 


\section{Sub structure II}

The effect of the quality of education services on student confidence is shown in Table 9.

Table 9. The Effect of Education Service Quality (X) on Student Trust (Z1)

\begin{tabular}{cccc}
\hline Variabel & Koefisien Path & Sig(p) & R Square \\
\hline $\mathrm{X} \rightarrow \mathrm{Z}_{2}$ & 0,641 & 0,000 & 0,411 \\
\hline
\end{tabular}

Table 9 shows that the probability value $(\rho)$ of the quality of education services (X) on student confidence (Z2) is 0.000 because $(\rho)<0.05$ then the error level of $5 \%$ is significant. This means that the quality of educational services has an effect on student confidence.

$\varepsilon=\sqrt{1-R^{2}}=\sqrt{1-(0,411)^{2}}=\sqrt{0,831079}=0,831$

If the results of this path analysis are described in sub-structure II, it will be seen in Figure 3.

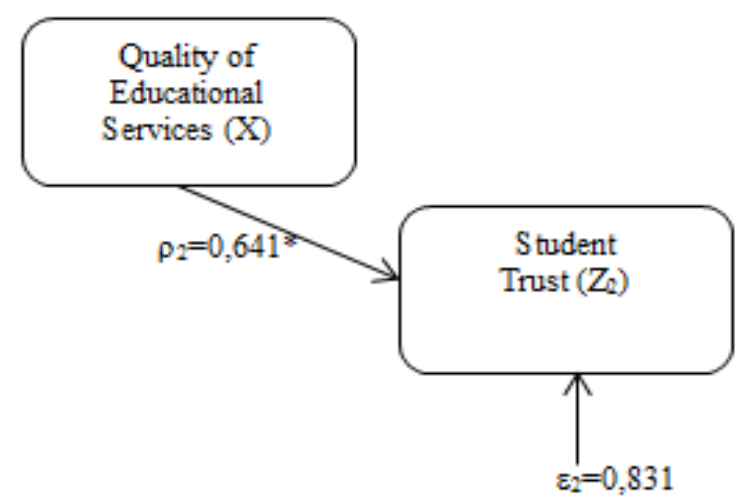

Figure 3. The Effect of Quality of Education Services on Student Trust

With the equation $\quad Z_{2}=\rho Z_{2} X+\varepsilon_{2}$

$$
Z_{2}=0,641 X+0,831
$$

This means that the equation shows that the variable quality of education services (X) has a significant direct effect on student confidence (Z2) of 0.641. From this it is known that there is an influence of the quality of education services on student confidence with an error of 0.831 .

\section{Sub structure III}

The effect of educational service quality, perceived cost of education, and student confidence on student satisfaction is shown in Table 10. 
Table 10. The Influence of Education Service Quality (X), Perception of Education Costs (Z1), and Student Trust (Z2) on Student Satisfaction (Y)

\begin{tabular}{cccc}
\hline Variabel & Koefisien Path & Sig(p) & R Square \\
\hline $\mathrm{X} \rightarrow \mathrm{Y}$ & 0,181 & 0,013 & \\
$\mathrm{Z}_{1} \rightarrow \mathrm{Y}$ & 0,185 & 0,004 & 0,461 \\
$\mathrm{Z}_{2} \rightarrow \mathrm{Y}$ & 0,425 & 0,000 & \\
\hline
\end{tabular}

Table 10 shows that the probability value $(\rho)$ of the quality of education services to student satisfaction is $0.013<0.05$, so at the $5 \%$ error level the path is significant. This means that the quality of educational services has a direct effect on student satisfaction. The probability value $(\rho)$ of the perception of the cost of education to student satisfaction is $0.004<0.05$, so at the $5 \%$ error level the path is significant. This means that the perception of the cost of education has a direct effect on student satisfaction. The probability value $(\rho)$ of student confidence in student satisfaction is $0.000<0.05$, so at the $5 \%$ error level the path is significant. This means that student confidence has a direct effect on student satisfaction.

$\varepsilon=\sqrt{1-R^{2}}=\sqrt{1-(0,461)^{2}}=\sqrt{0,787479}=0,787$

If the results of this path analysis are described in sub-structure III, it will be seen in Figure 4.

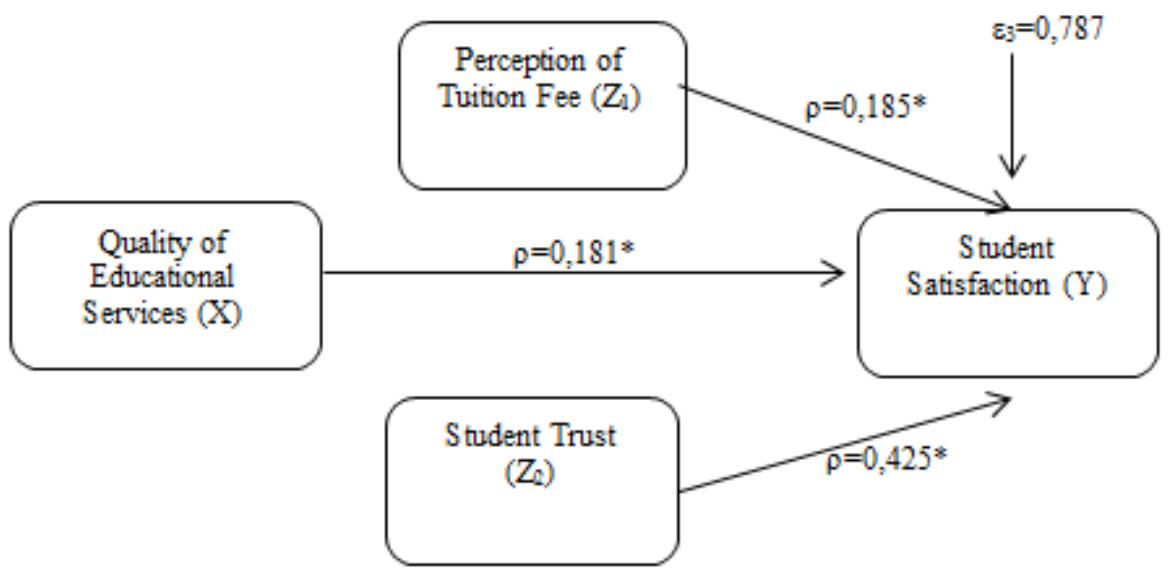

Figure 4. The Influence of Education Service Quality, Perception of Tuition Fees, and Student Trust on Student Satisfaction

With the equation $\quad \mathrm{Y}=\rho \mathrm{YX}+\rho \mathrm{YZ}_{1}+\rho \mathrm{YZ}_{2}+\varepsilon_{3}$

$$
Y=0,181 X+0,185 Z_{1}+0,425 Z_{2}+0,787
$$

This means that the equation shows that the quality of education services has a significant direct effect on student satisfaction of 0.181 . The perception of the cost of education has a significant direct effect on student satisfaction of 0.185 . As well as student confidence has a significant direct effect on student satisfaction of 0.425 with an error of 0.787 . 


\section{Combination of sub structure I, II, and III}

In the following, a combined diagram of sub structure I, sub structure II, and sub structure III will be presented which can be described as follows:

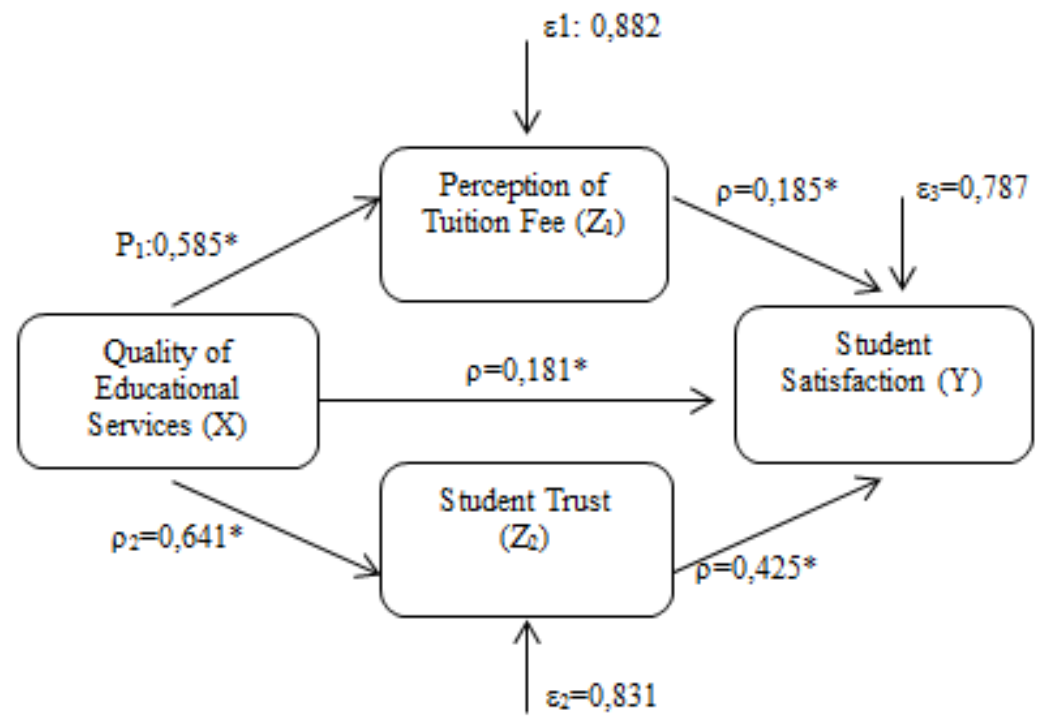

Figure 5. Combined Analysis of Sub Structures I, II, and III

Based on Figure 5, it is known that the quality of education services, perceptions of educational costs, and student trust have a significant effect on student satisfaction either directly or indirectly. The following describes the calculations both directly and indirectly between variables shown in Table 11.

Table 11. Variable Direct and Indirect Contribution

\begin{tabular}{ccccrr}
\hline No. & Variabel & Direct & Indirect & Total & \multicolumn{1}{c}{ SE } \\
\hline 1. & $\mathrm{X} \rightarrow \mathrm{Z} 1$ & 0,585 & - & 0,585 & $34,22 \%$ \\
2. & $\mathrm{X} \rightarrow \mathrm{Z} 2$ & 0,641 & - & 0,641 & $41,09 \%$ \\
3. & $\mathrm{Z} 1 \rightarrow \mathrm{Y}$ & 0,185 & - & 0,185 & $3,42 \%$ \\
4. & $\mathrm{Z} 2 \rightarrow \mathrm{Y}$ & 0,425 & - & 0,425 & $18,06 \%$ \\
5. & $\mathrm{X} \rightarrow \mathrm{Y}$ & 0,181 & - & 0,181 & $3,28 \%$ \\
6. & $\mathrm{X} \rightarrow \mathrm{Y}$ by $\mathrm{Z}_{1}$ & 0,181 & $0,585 * 0,185=0,108$ & 0,289 & $8,35 \%$ \\
7. & $\mathrm{X} \rightarrow \mathrm{Y} \mathrm{by}_{2}$ & 0,181 & $0,641 * 0,425=0,272$ & 0,453 & $20,52 \%$ \\
\hline
\end{tabular}

Table 11 shows that the variable that gives a large contribution is the variable quality of education services (X) on student confidence (Z2) of $41.09 \%$. Then the variable that gives a small contribution is the quality of education education services $(\mathrm{X})$ to student satisfaction $(\mathrm{Y})$ of $3.28 \%$. This shows that the quality of education services $(\mathrm{X})$ will directly and indirectly affect student satisfaction (Y). In this case, there are variables, namely the perception of the cost of education (Z1) and student confidence (Z2). 
a. The effect of the quality of education services on the perception of the cost of education

Based on the data analysis and hypothesis testing that have been carried out in this study, the results show that there is a significant effect between the quality of educational services on the perception of the cost of education. This means that the better the quality of educational services provided by the school, the more students will perceive positively the cost of education provided by the school. In accordance with the opinion of Lupiyoadi \& Hamdani (2008), states that the various benefits possessed by a product/service must be compared with the various costs incurred in consuming the service. Often also in determining the value of an item/service, students compare the ability of a service to meet their needs with the ability of substitute services, the perception that often applies is that high costs reflect high quality.

\section{b. The Effect of Educational Service Quality on Student Trust}

Based on data analysis and hypothesis testing that have been carried out in this study, the results showed that there was a significant effect between the quality of educational services on student confidence. This means that the better the quality of educational services provided by the school, the more students will trust the services provided by the school. In accordance with research (Loureiro et al., 2014), defining student trust is the expectation that students have for schools for the reliability of services and the reliability of schools in fulfilling their promises. Trust can be formed at a certain time based on customer satisfaction.

\section{c. The Effect of Perceived Educational Costs on Student Satisfaction}

Based on data analysis and hypothesis testing that have been carried out in this study, the results showed that there was a significant influence between the perception of the cost of education on student satisfaction. This means that the more positive students perceive the cost of education, the higher the satisfaction felt by students. In accordance with the opinion of Lupiyoadi \& Hamdani (2008), states that the various benefits possessed by a product/service must be compared with the various costs incurred in consuming the service. If the service received/perceived as expected, then the service quality is perceived to be good/satisfactory and vice versa (Suarman et al., 2011)..

\section{d. The Effect of Student Trust on Student Satisfaction}

Based on data analysis and hypothesis testing that have been carried out in this study, the results showed that there was a significant influence between student confidence on student satisfaction. This means that the more students believe in the education in the school, the higher the satisfaction felt by students. The quality of educational services provided by the school is expected to be able to create positive perceptions and students' trust in the school and result in student satisfaction. Service quality can also create trust as a psychological variable that 
describes an accumulation of presumptions that show the credibility, integrity and good name of a service in the eyes of customers (Cisse et al., 2009).

\section{e. The Effect of Educational Service Quality on Student Satisfaction}

Based on the data analysis and hypothesis testing that have been carried out in this study, the results showed that there was a significant influence between the quality of educational services on student satisfaction. This means that the better the quality of educational services provided by the school, the higher the satisfaction of students. In accordance with the opinion of Kotler \& Armstrong (2008), satisfaction is a person's level of satisfaction after comparing the performance or perceived results compared to their expectations. So satisfaction or dissatisfaction is formed from the interaction between expectations and experiences after using the services or services provided.

f. The Effect of Educational Service Quality on Student Satisfaction Through Perception of Educational Costs

Based on data analysis and hypothesis testing that have been carried out in this study, the results showed that there was a significant influence between the quality of educational services on student satisfaction through the perception of education costs. This condition shows that students who have a positive perception of the cost of education can provide a strong influence on the quality of educational services with student satisfaction. Service quality is the expected level of excellence and control over the level of excellence to meet customer desires. In this case, there are two main factors that affect service quality, namely expected service and perceived service. If the service received or perceived is as expected, then the service quality is perceived as good or satisfactory (Suarman et al., 2011).

g. The Effect of Educational Service Quality on Student Satisfaction Through Student Trust

Based on data analysis and hypothesis testing that have been carried out in this study, the results showed that there was a significant influence between the quality of educational services on student satisfaction through student trust. This condition shows that students who have high confidence in the education in schools can provide a strong influence on the quality of education services with the satisfaction felt by students. The quality of educational services provided by the school is expected to be able to create positive perceptions and students' trust in the school and result in student satisfaction. Service quality can also create trust as a psychological variable that describes an accumulation of presumptions that show the credibility, integrity and good name of a service in the eyes of customers (Cisse et al., 2009). 


\section{Conclusion}

Based on the results of descriptive analysis, the quality of education services, perceptions of education costs, student confidence, and student satisfaction are in the medium category. The quality of education services affects the perception of the cost of education. The quality of educational services has an effect on student confidence. Perception of the cost of education has an effect on student satisfaction. Student trust has an effect on student satisfaction. The quality of educational services has an effect on student satisfaction. The quality of educational services affects student satisfaction through the perception of the cost of education. The quality of educational services affects student satisfaction through student trust.

\section{References}

Cisse, K. D., \& N'Goala, G. (2009). The effects of satisfaction, trust and brand commitment on consumers decision to boycott. Recherche et Application en Marketing, 24(1), 43-66.

Desmita, Y., Suarman., \& Gimin. (2021). Pedagogic and professional competencies of social science subject teachers in relation to motivation and learning achievement. Journal of Educational Sciences, 5(1), 188-197.

Indrawati, H. (2013). Upaya peningkatan kompetensi profesional guru mata pelajaran ekonomi dalam proses pembelajaran. Jurnal Pendidikan,4(2), 84-95.

Indrawati, H. (2019). Analysis of economic learning success. International Journal of e-Collaboration (IJeC), 15(4), 18-30.

Irawan, H., \& Juwandi. (2004). Kepuasan pelayanan jasa. Jakarta: Erlangga.

Kotler, P., \& Amstrong, G. (2008). Prinsip-prinsip pemasaran (12 ed). Jakarta: Erlangga.

Loureiro, S.M.C., Miranda, F. J., \& Breazeale, M. (2014). Who needs delight? The greater impact of value, trust and satisfaction in utilitarian, frequentuse retail. Journal of Service Management, 25(1), 101-124.

Lupiyoadi, R., \& Hamdani, A. (2008). Manajemen pemasaran jasa. Jakarta: Salemba Empat.

Mahmud, M. (2012). Manajemen mutu perguruan tinggi. Jakarta: PT. Raja Grafindo Persada.

Murty, Y. H. (2014). Pengaruh kualitas layanan pendidikan terhadap persepsi dan kepercayaan siswa serta dampaknya terhadap kepuasan siswa di SMA Santo Ignasius Singkawang.

Siagian, D., Rukun, K., Marsidin, S., \& Anwar, S. (2018). Managerial development model of head of SMA in Padangsidempuan to acieve quality school. Journal of Educational Sciences, 2(1), 91-105.

Suarman., Sumarno., \& Arum. (2011). Analisis kepuasan mahasiswa terhadap kualitas pembelajaran dosen program studi pendidikan ekonomi FKIP Universitas Riau. Jurnal Pendidikan Ekonomi dan Bisnis, 3(3), 549-559.

Sugiyono. (2013). Metode penelitian pendidikan pendekatan kuantitatif, kualitatif, dan $R \& D$. Bandung: Alfabeta. 
Suhardan., \& Suharto. (2009). Manajemen pendidikan. Bandung: Alfabeta.

Sumaedi, S., Bakti, I. G M. Y., \& Metasari, N. (2011). The effect of student's perceived service quality and perceived price on student satisfaction. Management Science and Enginering, 5(1), 88-97.

Suryadi, A. (2010). Permasalahan dan alternatif kebijakan peningkatan relevansi pendidikan (Studi relevansi pendidikan kerjasama UPI dengan balitbang Kemendiknas. In Makalah Seminar Internasional Luar Sekolah.

Sutriayu., Makhdalena., \& Sumarno. (2020). Effect of family environment and education costs on student achievement with interest in reading as an intervening variable. Journal of Educational Sciences, 4(1), 164-175.

Tjiptono, F. (2015). Strategi pemasaran (4 ed). Yogyakarta: Andi.

Wijaya, D. (2009). Implikasi manajemen keuangan sekolah terhadap kualitas pendidikan. Jakarta: Bumi Aksara.

Wuryan, S., \& Legowo, D. (2009). Pengaruh citra lembaga, kepercayaan mahasiswa terhadap kepuasan mahasiswa dan implikasinya kepada komitmen relasional mahasiswa pada Fakultas Ekonomi Universitas Negeri Semarang. Telaah Manajemen, 6(2), 119-131.

How to cite this article:

Syafriani, S., Suarman, \& Indrawati, H. (2021). The Effect of Quality of Education Services on Perceptions of Educational Costs and Student Trust and Their Impact on Student Satisfaction at SMA Negeri Ujungbatu. Journal of Educational Sciences, 5(3), 448-463. 